\author{
Olga Polyakova \\ Research Centre for Industrial Problems of Development of the NAS of Ukraine \\ 1a Inzhenernyi Ln., Kharkiv, 61166, Ukraine, polya_o@ukr.net \\ Viktoriia Shlykova \\ Research Centre for Industrial Problems of Development of the NAS of Ukraine \\ 1a Inzhenernyi Ln., Kharkiv, 61166, Ukraine, v.shlykova@ukr.net
}

\title{
INNOVATION FACTORS IN THE CYCLICAL DEVELOPMENT OF UKRAINIAN INDUSTRIES
}

\begin{abstract}
This article deals with the determination of the stages of development of Ukrainian industries with regard to the factors driving innovation. Based on an analysis of literary sources carried out, the most common indicators of the stages of development of industries have been identified, and it is proposed to classify them into structural, volumetric, dynamic, and innovation ones, given the specificity of the relevant statistical data regarding Ukraine. Calculations have shown that most industries are in a declining phase in terms of the majority of volumetric and innovation criteria. In some industries there are positive trends to intensify the innovation activity of businesses, while the chemical and engineering industries, which have the highest level of technological development, are in a decline phase.
\end{abstract}

Key words: industries, cyclical development, stages of development, innovation factors

\section{Introduction}

The global financial crisis has shown that the real economy, as opposed to the financial sector, is more stable and that it creates most of the products and jobs in developed countries.

The process of deindustrialization of the Ukrainian economy has been going on for more than two decades. In the period 2001-2016, the share of industry in GDP declined by 10 percentage points. Only low- and mediumtechnology production - the manufacture of food, the manufacture of basic metals, and mining demonstrated the highest rate of development and relative stability. At the same time, a continuous reduction in the volumes of production, investment, and employment has been observed in the engineering industry, which belongs to high-tech industries. The European Commission called on the governments and societies of EU member states to restore industry as the main driving force of economic and social development. As highlighted in the relevant communiqué, a strong manufacturing base will be the key to restoring Europe's economy and competitiveness in the coming years, because industry provides the largest multiplier effect in the economy of countries as a whole, creating the largest volumes of added value. That is why, in EU countries, there are widely used various forms of government support for the development of a new type of industry, which are intended to restore and maintain the EU leadership in global industrial production in the long term.

The deepening crisis in Ukraine's industry does not allow the execution of simultaneous reconstruction in all directions, therefore, when providing support the government should take into account the state the stage of development, and potential of each specific industry in the economy.

The need to determine the stages of the development of industry in order to form an effective industrial policy is noted both by national [1] and foreign [2] researchers.

Thus, the purpose of the study is to determine the stages of development of Ukrainian industries with regard to the factors driving innovation.

\section{Literature review}

In modern literature, from 3 to 6-9 stages of development of industry are distinguished. The traditional life cycle model is associated with the development of $\mathrm{M}$. Porter and includes four stages of development: 
introduction, growth, maturity, and decline (crisis). Many researchers follow this approach. A detailed analysis of the characteristics of the four stages of industry development is presented in [3, 4]. Unlike Porter's approach, the Moore model is based on consumer requirements for products in an industry, and it comprises three phases: functionality, reliability, and convenience, which correspond to the improvement of technologies in order to satisfy consumer needs.

Given the possibility of different scenarios of industrial development when technologies become obsolete, the decline phase can end in the complete disappearance of an industry, or its transition to a new state of equilibrium (with a much smaller production volume) with the old technology being preserved.

Existing approaches to defining the concept of a life cycle and the correlation of stages, mostly for characterising the development of an enterprise, are studied in detail in the work of $O$. Matiushenko [5].

In general, approaches to determining the stage of development of an industry can be divided, depending on the preferential use of individual indicators, into the following groups:

- quantitative approaches, which primarily consider the volumes of factors involved and the results of production;

- innovative approaches, which are based on the assumption of the leading role of innovations in the development of an industry;

- complex approaches, which use a wide range of indicators to assess an industry's stage of development;

- individual approaches, which have a limited scope of use due to the specificity of an industry.

With a quantitative approach, the most applicable are indicators of production, sales, investments, employment, resources, etc.

S. Smirnova [6] considers the development of industrial clusters and proposes the use of methods of multivariate analysis to determine the stage of their life cycle. The feature space to characterise enterprises and clusters includes the following indicators: the current state of the market; the forecast state of the market; the intensity of competition; the availability of raw materials; and the availability of labour resources.

Based on the concept suggested by M. Porter, N. Rychyhina determines the development stages of the manufacture of textiles [7] and engineering [8] using the following main criteria: the number of enterprises; the production volume in physical and monetary terms; the number of employed; the number of equipment upgrades; the introduction of advanced technologies; the number of newly developed products (in the most recent period); and financial results.

The reasons for skipping one of the stages of the life cycle ("closing up", decline) by industries with a high degree of vertical integration, which do not experience any exit from the market, are analyzed in [9] using the example of the manufacturing of jet engines for civil aviation. The high degree of vertical integration of the network of engine and aircraft manufacturers prevents mass entry into and exit from the industry and provides a certain degree of stability. A life cycle analysis is based on the number of manufacturers and their production links. It should be noted that, at the stage of introduction of this industry, the main role was played by the experience of industry producers for the purpose of military aviation, which created large entry barriers for other potential participants. The features of such industries should be taken into account when analyzing the stages of their life cycle.

Innovative approaches to assessing the stage of development of an industry (known as the AbernathyUtterback model), based on the leading role of innovation in economic development and the change of technological modes, focus on expenditure on $R \& D$, and innovation, the volume of new and innovative products, the R \& D intensity of an industry, etc., the degree of specialization / unification of equipment and products [10]. The peculiarity of each stage in terms of the origin of innovations is shown in [11], which points to the introduction of innovations at the early stages of development from other technologically related industries, in contrast to the later stages, where innovations have an endogenous origin.

An original approach to assessing the level of innovation development of an industry is proposed in [12], where authors distinguish between innovation potential and innovation activity, with innovation potential being adjusted in accordance with the level of innovative risk that reduces the potential. The authors use a uniform 
scale to identify the level of innovation activity in different situations. Thus, the main criterion for determining the stage of development of an industry is the level of its innovational activity. The disadvantage of this approach is that among the singled out situations (stages), namely: "introduction", "formation", "smooth implementation" and "stability", there is no general crisis stage (decline). Thus, the indicators of innovational activity are not enough to determine the stage of development of an industry if they are not analysed in longterm dynamics.

Innovative processes are considered by S. Kuznetsov as the key factor in altering the stage of an industry's life cycle [13]. The main idea of defining the cycles of an industry is based on the hypothesis of the exhaustion of innovations, i.e., the decrease in efficiency of the available technologies, which leads to the decline of the industry. However, a higher innovational activity in industries related to the selected one (in the author's research - the forestry industry) can extend the maturity and efficiency of the industry.

Within the framework of an innovative approach, some researchers suggest using the idea of the existence of two types of threats of obsolescence - the threat to core activities and the threat to core assets - to define an industry's life cycle [10]. Obsolescence of core activities refers to the key factors that ensured the industry's profitability in the past, the obsolescence of core assets (competitiveness) is associated with knowledge, brands, patents, etc., which ensure the uniqueness of the organization in the market.

Comprehensive assessments include a variety of indicators that are usually combined into an integral indicator.

To assess the level of technological development of industries, L. Strelkova and S. Kabanov [14] propose the use of 20 indicators, which are grouped as follows: the efficiency of using fixed assets; innovative products and new technologies; organizations that implement technological innovations and their co-operation; use of human resources in the field of $R \& D$; the operating costs associated with technological innovation; and intellectual property. The methodology involves the construction of an integral indicator of the level of an industry's technological development as a weighted sum of sub-indices.

Based on an analysis of 21 manufacturing industries in six European countries, the authors [15] investigated the innovational activity of new and existing firms at different stages of their life cycle. The initial assumption was the endogenous nature of economic growth associated with investing in R \& D to create innovation. The authors distinguished two types of innovations (aimed at increasing t efficiency and qualitative characteristics) and determined the conditions of using one or another type at different stages of a firm's life cycle by the method of stochastic boundary estimation. Determining the stages of an industries' life cycle is based on panel data on production volume, value added, investment, labour costs and expenditure on $R \& D$. The interpretation of quadratic models of panel data on countries' sales volumes (presented as logarithms) allows the determination of the stages of growth and maturity of an industry. The first derivative of these models makes it possible to determine the degree of maturity: industries with the highest degree of maturity are oil refinery, textile production and shipbuilding; with the lowest degree of maturity - production of computer equipment, communication equipment, pharmaceuticals and the precision instruments industry.

Some researchers have suggested identifying the stages of the life cycle of industries in terms of the quadrants of the BCG matrix. The transitions between the stages correspond to the transitions between quadrants [16], which allows consideration of regression processes in industries.

Regional features of the life cycle stages of the mining industry are associated with the exploration, use and exhaustion of stocks, as well as the availability of innovative technologies, as described in [17]. The difference in the life cycle stages of the industry in different regions affects the duration of the life cycle stages of the entire industry. The main criterion for determining the stages of the life cycle is the average annual increase in the volume of production, which is the largest in the stage of growth, and approaches zero in the maturity phase.

It is proposed to use economic and mathematical modeling for distinguishing the stages of growth - slow and rapid. Based on the data on gross revenue, capitalization, the number of employees, current liquidity, financial leverage, and taking into account the industry affiliation of a company, in [18] a probit-model of the transition of a company to the stage of rapid growth was constructed. In the paper it is shown that a decrease in the likelihood of transition to the stage of rapid growth is typical for industrial enterprises, which is mainly due to 
the growth of debts hindering rapid growth. A detailed analysis of empirical methods to identify the stages of the life cycle of industries or products is given in [19].

Grebel et al. [20] focus on the peculiarities of the life cycle stages of the knowledge-oriented industries that arose in the late $20^{\text {th }}$ century. The authors note that the concept of a life cycle, which was developed during the $20^{\text {th }}$ century, has a very limited application in relation to new industries. A peculiarity of the development of such sectors is the simultaneous existence of large, highly differentiated firms, those oriented towards new technologies, which interact with state research institutes within a single innovation space. Due to this, the diffusion of knowledge and innovation is moving at a faster rate. The dynamics of the life cycle for knowledgeoriented industries is determined by the processes of transferring knowledge and technologies. Thus, the main criteria for determining the stage of the life cycle are the emergence and degree of implementation of new technologies, the specialization of new and reorientation of existing firms, as well as the growth rate of new knowledge. A quantitative measure may be the number of new patents (growth index), and the degree of concentration in the industry.

M. van Dijk [21] presents an empirical examination of differences between the dynamic and structural characteristics of industries that are in different stages of development, using the example of the Dutch economy. The formulated hypotheses are based on the Klepper innovative model of the life cycle of an industry, which implies a dynamic increase in the return on technological changes and takes into account the innovative opportunities and scale of the firm. The survey covered a period of 15 years and considered more than 10 thousand firms, of which 2.8 thousand existed throughout the period and provided more than half of the jobs and volume of sales. The list of indicators that were investigated for each firm comprised: the number of hired workers, sales volume (including re-exports), gross output, gross intermediate consumption, gross value added, indirect taxes, labour costs (including deductions to social funds), and gross profit.

To determine what stage of the lifecycle an industry is in, M. van Dijk [21] uses only two indicators: the growth rate of the total number of firms, and the growth rate of gross sales during the period under study. To assess an industry's stage of development by rate of growth/decline, we used the scale to estimate the significance of the deviation from zero "significantly smaller than zero", "zero", "significantly greater than zero", which was tested using the Student's criterion. At present, the approach is not applicable to determine the stages of development of Ukrainian industries, as it involves a large sample of data on the primary elements of industries - businesses - over a long period of time.

Thus, the list of indicators used to determine the stage of development of different economic sectors (including manufacturing ones) is wide enough (Tab. 1).

Table 1. Indicators of the stages of development of industries used in global practice

\begin{tabular}{|l|l|l|}
\hline \multicolumn{1}{|c|}{ Industry structure } & \multicolumn{1}{|c|}{ Production activity } & \multicolumn{1}{c|}{ Innovation activity } \\
\hline Number of enterprises & Volume of production (sales) & $\begin{array}{l}\text { Innovation activity of enterprises } \\
\text { (including large and small ones) }\end{array}$ \\
\hline $\begin{array}{l}\text { Rate of change in the number of } \\
\text { enterprises }\end{array}$ & Rate of change in volumes of production & Expenditure on innovation activity \\
\hline $\begin{array}{l}\text { Degree of concentration in the } \\
\text { industry }\end{array}$ & Financial results & Expenditure on R \& D \\
\hline $\begin{array}{l}\text { Share of the industry in the } \\
\text { domestic market }\end{array}$ & Export volumes & $\begin{array}{l}\text { Number of implemented innovative } \\
\text { technologies }\end{array}$ \\
\hline Risk level & Depreciation of fixed assets & Number of patents received \\
\hline Share of small enterprises & Volume of capital investments & Volume of sales of innovative products \\
\hline Level of competition & Product turnover & \\
\hline \multirow{5}{*}{} & Volume of orders & \\
\cline { 2 - 2 } & Dynamics of prices for products & \\
\cline { 2 - 2 } & Profitability & \\
\cline { 2 - 2 } & Structure of capital & \\
\cline { 2 - 2 } & Number of employees & \\
\hline
\end{tabular}

Source: Author's 
The first set of indicators reflects an approach in which the main emphasis is placed on the rate of growth (decrease) in the number of firms over a certain period, the time when the number of firms is the greatest and the number of years when the growth (decrease) in the number of firms is observed. It should be noted that different methods allow the definition of a different number of stages of development of the industry - from two (growth - fall) to five.

The second group corresponds to Porter's quantitative approach. Therefore, the main focus is on volumes of resources, the efficiency of use, results, and the number of employed used as an additional criterion.

The formation of the third group of indicators is based on the suggestion that the innovational activity is high at the initial stages and is low at the stage of stability and decline. Moreover, the phase of introduction and the phase of decline of innovation is predominantly inherent in small businesses. For identification, direct indicators (the volume of sales of innovative products) and indirect ones (including the number of patents, expenditure on R \& D) are applied. To use them, a targeted survey of business entities is necessary [19]. It is the activity in obtaining patents that is considered as a sign of the stage of technological development of an industry [22].

The possibilities of using certain indicators to determine the stages of development of Ukrainian industries are limited by the availability of relevant information for a long period of time. Therefore, in the case of Ukraine, the criteria shown in Figure 1 will be used.

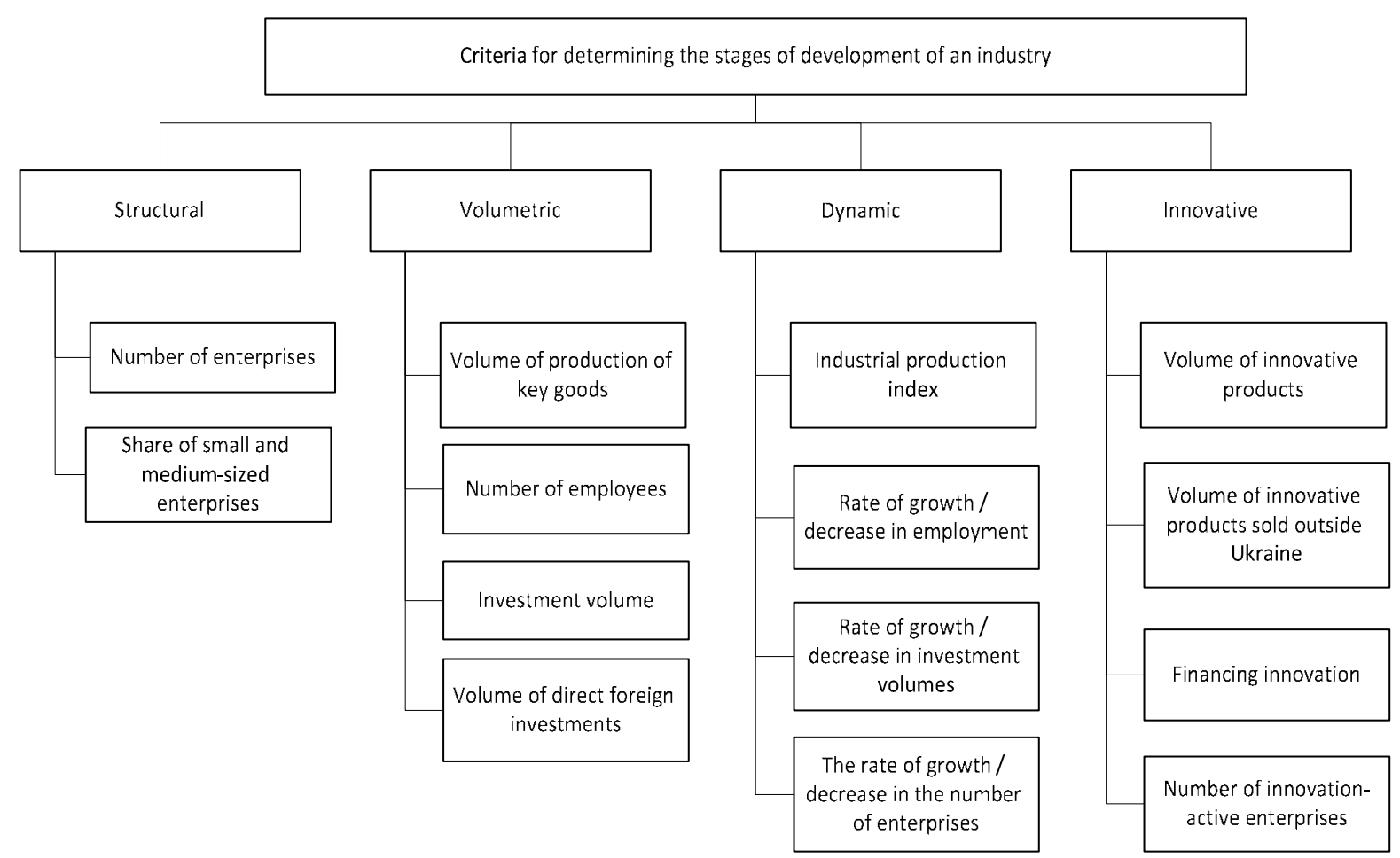

Fig. 1. Classification of criteria for identifying the stages of the life cycle of Ukrainian industries Source: Author's

The structural and volumetric criteria for determining the stages of development of industries are used to carry out a preliminary analysis and calculate dynamic indicators. Dynamic indicators are calculated in the form of a chain and basic rates of growth (increase) are used for the formal definition of the development stage. Innovation criteria are used to assess the technological level and potential of development of an industry at the current stage. In view of the significant influence of inflationary processes, preference should be given to physical indicators or to those that are assigned in the same comparative base.

Thus, assessing the stage of development of Ukrainian industries according to the proposed criteria will make it possible to simultaneously reveal the main problems of the development of industries, with regard to their place in the country's economy, social impact, and the degree of technological development. 


\section{Assessing the stages of development of Ukrainian industries}

To determine the features of the stages of development of Ukrainian industries based on the criteria presented in Figure 1, the data of the State Statistics Service of Ukraine for 2001-2015 [23, 24, 25, 26, 27] were used.

To determine the stage of development of Ukrainian industries an approach described in [21] was used, which is based on estimating the rates of growth / decline in the quantitative characteristics of businesses. According to this approach, to provide an absolute quantitative characteristic, the rate of growth/decline for a certain period of time is determined and then the hypothesis regarding the significance (non-significance) of the deviation of the rate of change from zero using Student's criterion is tested as follows:

Table 2. Deviation of the rate of change from zero using Student's criterion where $\tau$ is the rate of change of the quantitative indicator; $t$ is the calculated value of the Student's $t$-criterion, $t=1.75-$ the critical value of the Student's criterion at a level of confidence probability of 0.05 .

\begin{tabular}{|c|c|}
\hline Rate of change $(\boldsymbol{\tau})$ & Student's criterion \\
\hline significantly smaller than zero $(\tau<<0)$ & $t<-1.75$ \\
\hline approximately equal to zero $(\tau \approx 0)$ & $-1.75 \leq \mathrm{t} \leq 1.75$ \\
\hline significantly greater than zero $(\tau>>0)$ & $\mathrm{t}>1.75$ \\
\hline
\end{tabular}

Source: Author's

The calculations were carried out for the types of industrial activity the data on the development of which is available for at least 10 years. Due to the change in the classification of types of economic activity and the limited list of industrial activities, the assessment of the development stage was carried out by aggregate types of activity.

Figure 2 presents the dynamics of the number of mining enterprises, which demonstrates that during the period 2001-2007 there was an increase in their number due to the expansion of non-energy mineral extraction.

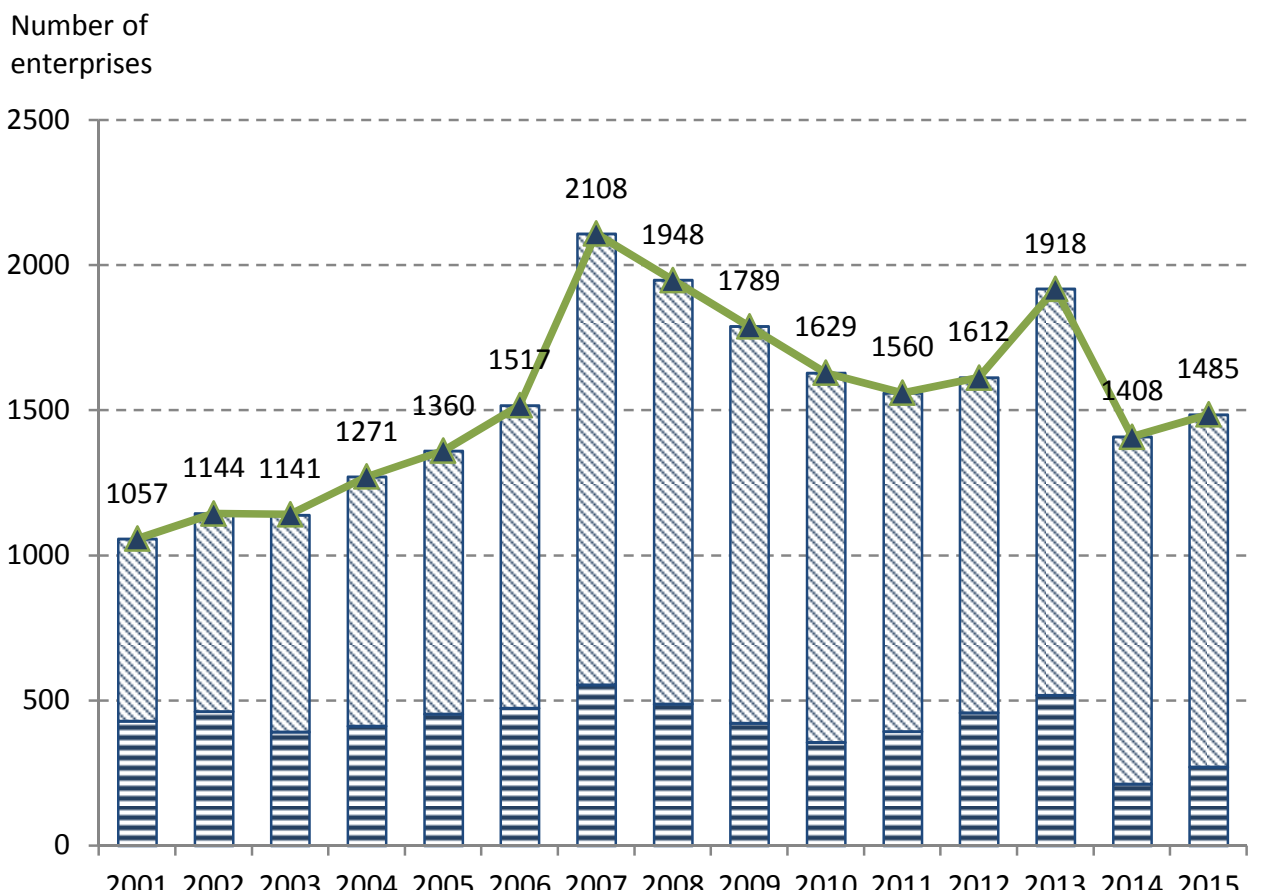

200120022003200420052006200720082009201020112012201320142015 Years

Extraction of minerals with the exception of fuel and energy

Extraction of fuel and energy minerals

$\triangle$ Mining and quarrying

Fig. 2. Dynamics of the number of mining enterprises Source: Author's 
Since 2008, a general decrease in the number of enterprises involved in this type of activity has been observed, mainly due to the fall in the number of enterprises specialising in the mining of hard coal and lignite (from 280 to 157).

The dynamics of the number of enterprises in some types of manufacturing industries is shown in Figure 3 . In general, manufacturing also experienced a decrease in the number of enterprises, including the largest types of industrial activity.

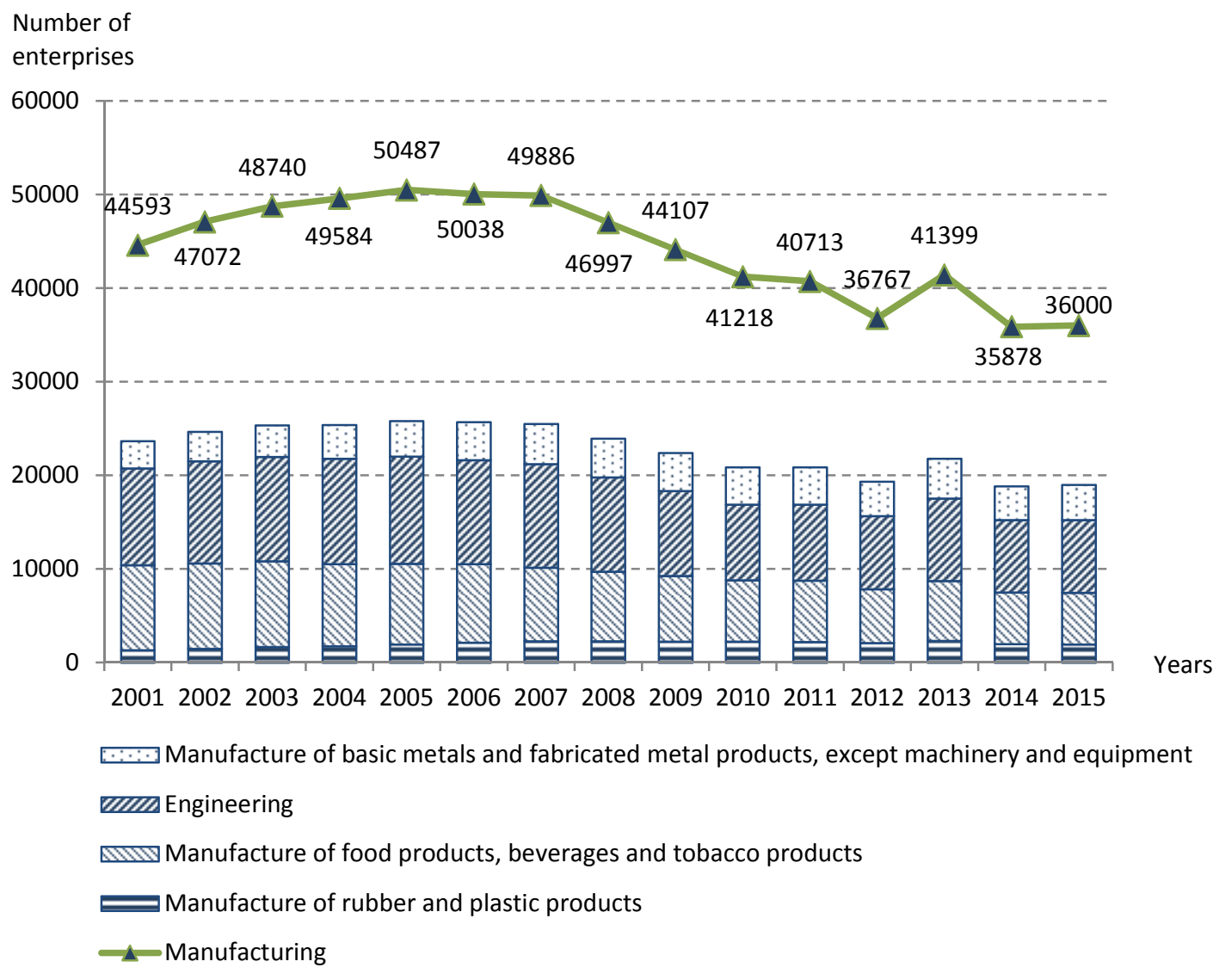

Fig. 3. Dynamics of the number of enterprises in the manufacturing industry by the largest types of industrial activity Source: Author's

The results of calculating the rate of change in the number of businesses by selected industrial activities showed that two periods can be distinguished in the dynamics of the number of enterprises in almost all types of industrial activities. The first period - from 2001 to 2007 (for some industries, the period from 2001 to 2005) - is characterized by an increase in business activity and, in most cases, positive rates of increase in the number of businesses. The second period - from 2008 to 2015 (or from 2006 to 2015) - is characterized by a decline in business activity, a decrease in the number of enterprises, and negative rates of change in almost all industries. The largest decrease was recorded in 2014, which is partly due to excluding the data on the Autonomous Republic of Crimea from the calculation. However, the total number of enterprises of various industries in the AR of Crimea did not exceed $3 \%$ of the total number of enterprises in the country, while the fall reached 9-14 \%, i.e., it was significantly higher than the objectively conditioned.

The analysis of the calculated values of the Student's criterion confirms the significant fluctuations in the number of businesses during the two periods under consideration. To determine the current stage of the development of the industries, the rates of change in relation to the reference year of 2001 were used. The results of the calculations showed that only three industries (non-energy mineral extraction, production of rubber and plastic products, and manufacture of basic metals) are in the growth stage by the number of businesses. At the same time, Ukrainian industry, as a whole, is in the maturity phase (although it displays negative dynamics) while the manufacturing industry, in particular high-tech engineering, is in the decline 
phase. Thus, it once again confirmed the need to take measures for the reconstruction and revival of national industry.

It should be noted that since at the beginning of the second period in the industries whose phase was identified as "maturity", a decrease in the number of businesses was observed, this phase is closer to "overmaturity", i.e., it results from negative dynamics.

The preliminary analysis of the dynamics of employment in the industries based on the data on the number of staff in 2001-2015 showed a steady decline in employment rates in all types of industrial activities in favor of service industries, as shown in Figure 4.

Number of employees, ths. pers.

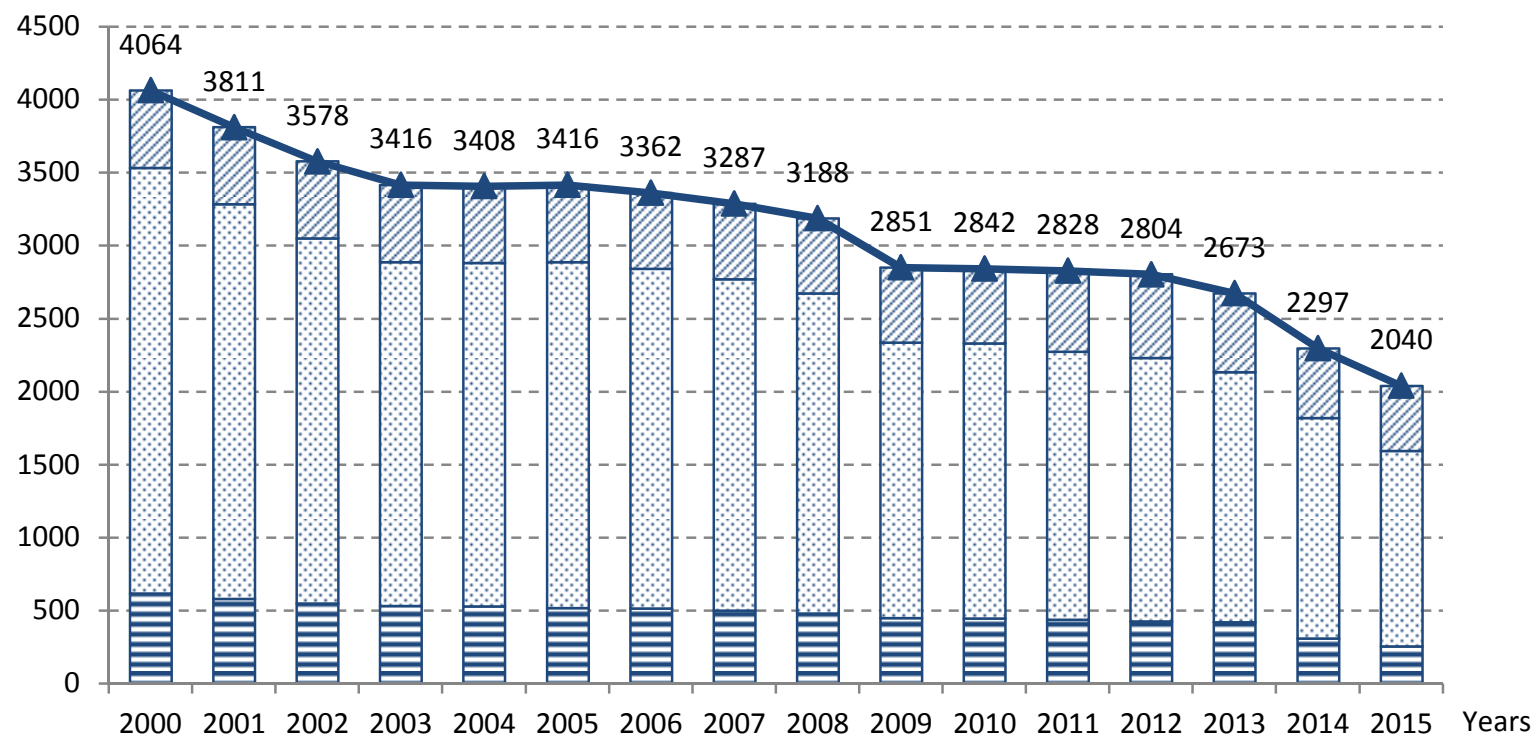

$\dddot{2}$ Production and distribution of electricity, gas and water

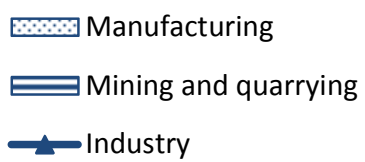

Fig. 4. Dynamics of the average number of staff in Ukrainian industry Source: Author's

The analysis performed of the chain rates of change in the number of employees by industry showed that the total trend in all sectors of the economy is determined by the negative rate of change in employment, while no rate that is significantly greater than zero was observed throughout the period under study. The only exception is wood processing; the pulp and paper industry, and publishing; the manufacture of rubber and plastic products and the manufacture of basic metals in the periods from 2003 to 2007 and from 2010 to 2011.

The results of the assessment of the rate of change in relation to the reference year of 2001 make it possible to state that all industries are in the phase of decline.

To analyse the stage of development of industries by volume of production, data was used regarding the production volumes of certain key homogeneous types of industrial products in physical terms for 2003-2006. A preliminary analysis of the data concerning such groups of products as finished steel, mineral fertilizers, sugar, etc., starting from1990, showed that in almost all industries there was a sharp decline in production in the period 1990-1996, even the production of oil decreased by $40 \%$ over the 5 years. Thus, it should be noted that since 1995-1996, the manufacturing of most products has reached a new equilibrium level after the crisis and a new, shorter, life cycle has begun. In the cycle, there is no period of introduction, and the growth rate was not high. To determine the current stage of development of industries, the data regarding the period from 2003 to 2016 were used. 
Chain rates of change in the volume of production suggest the presence of different stable and unstable trends in the development of industries. The most positive changes were observed in 2011, which is due to a gradual decrease in the impact of the global financial crisis of 2008-2009. Only one of the considered positions - the manufacture of synthetic dyes - demonstrated a positive growth rate throughout the whole period. A decline in the production volume of oil and sugar was also observed in 2013 and 2015. As evidenced by the data obtained as a result of calculating the Student's criterion, the growth rate was significantly greater than zero for most product positions. At the same time, in 2013-2014, the situation changed to the opposite, and the rate of change was significantly smaller than zero.

The basic rates of change in the production volumes in 2016 as compared to 2003 were used to assess the stage of development of the industries. The aggregation of the rate of change was carried out using the weighted average for all product positions that relate to a particular type of industrial activity:

$$
\tau_{i}^{a}=\sum_{j \in J_{i}} w_{j i} \tau_{j}
$$

where $\tau_{i}^{a}$ is the aggregate rate of change for industry $i$;

$j$ is the product position,

$J_{i}$ is the set of product positions that are relevant to industry $i$;

$w_{j i}$ is the weight coefficient, which is equal to the normalised value of the correlation coefficient of the rate of change in the production volume of product of type $j$ and the index of industrial production in industry $i$; $\tau_{j}$ is the rate of change in the production volume of product $j$.

The results of calculating the aggregate rates of change in the production volume of industries and the assessment of the stage of the industries' development showed that national industry in general and mining and manufacturing in particular are in the stage of maturity. This is due to the aggregation and mutual compensation in the rate of change in various types of industrial activity.

Only two industries - the manufacture of food products, beverages and tobacco products, and the manufacture of wood products and paper - are in the growth stage. Among mining industries, extraction of energy minerals is in the decline phase, primarily due to the loss of capacity in some districts of the Donetsk and Luhansk regions. The manufacture of coke and refined petroleum products, of chemicals, and engineering are in the decline phase as well. The significant decrease in the production volume in most positions of the engineering industry has had a considerable negative impact, since it is a high-tech one and should be among the industries of the real sector in the post- and neo-industrial economy. The positive trend is that the manufacture of electrical, electronic and optical equipment is in the stage of maturity, mainly due to a significant increase in the production volume of measuring equipment in recent years, mainly for the needs of housing and communal services. However, in most product positions of this type of engineering, there are also negative trends towards decline.

Investments in fixed assets, as a rule, differ considerably from the stages of the life cycle of an industry. For the analysis of investment processes, indices of investment in fixed assets were used, which made it possible to eliminate inflationary effects.

The calculations based on the Student's criterion show that in 2007 and from 2011 to 2012 investments significantly increased, while in 2014-2015, to the contrary, a significant decrease in the volume of investments in all industries was observed. At the same time, the growth of investments for the whole of the period under study was also significant.

It has been determined that a vast majority of industries are in the growth stage, with the exception of the manufacture of coke and refined petroleum products, whose stage of development is identified as decline. The data on the degree of depreciation of fixed assets contradict this conclusion, since throughout the period under study, the degree of depreciation was constantly increasing, or remained unchanged in all industries. The only exception is the metallurgical industry and the mining of metal ores. However, this is the result of the exclusion from the calculations of a part of the businesses which use considerably obsolete technologies that are located in the Donetsk and Luhansk regions. This indicates the ineffectiveness of investment in fixed assets, which is carried out only to replace the retired or completely operationally unserviceable assets. Thus, the application 
of this criterion to determine the stages of development of the Ukrainian industries is currently inexpedient, since it does not make it possible to make an objective assessment.

The analysis of the innovation component of Ukrainian industries was carried out in terms of the number of enterprises engaging innovation activity, the volumes of innovation products sold, incl. outside Ukraine, and expenditure on innovation activity. Since, starting from 2015, the data on their innovational activity include only the results of businesses with the number of employees totaling not less than 50 persons, direct comparison with the previous years is incorrect. Therefore, to identify the trends, the data for 2005-2014 were used.

In general, during 2005-2014, the number of industrial enterprises engaging innovation activity had a weak growth trend (Fig. 5), but in the high-tech chemical industry, there was a slowdown in the innovational activity of businesses. A sharp decline (from $38 \%$ to $28.6 \%$ ) occurred in the manufacture of coke and refined petroleum products.

Share of innovativeactive enterprises, \%

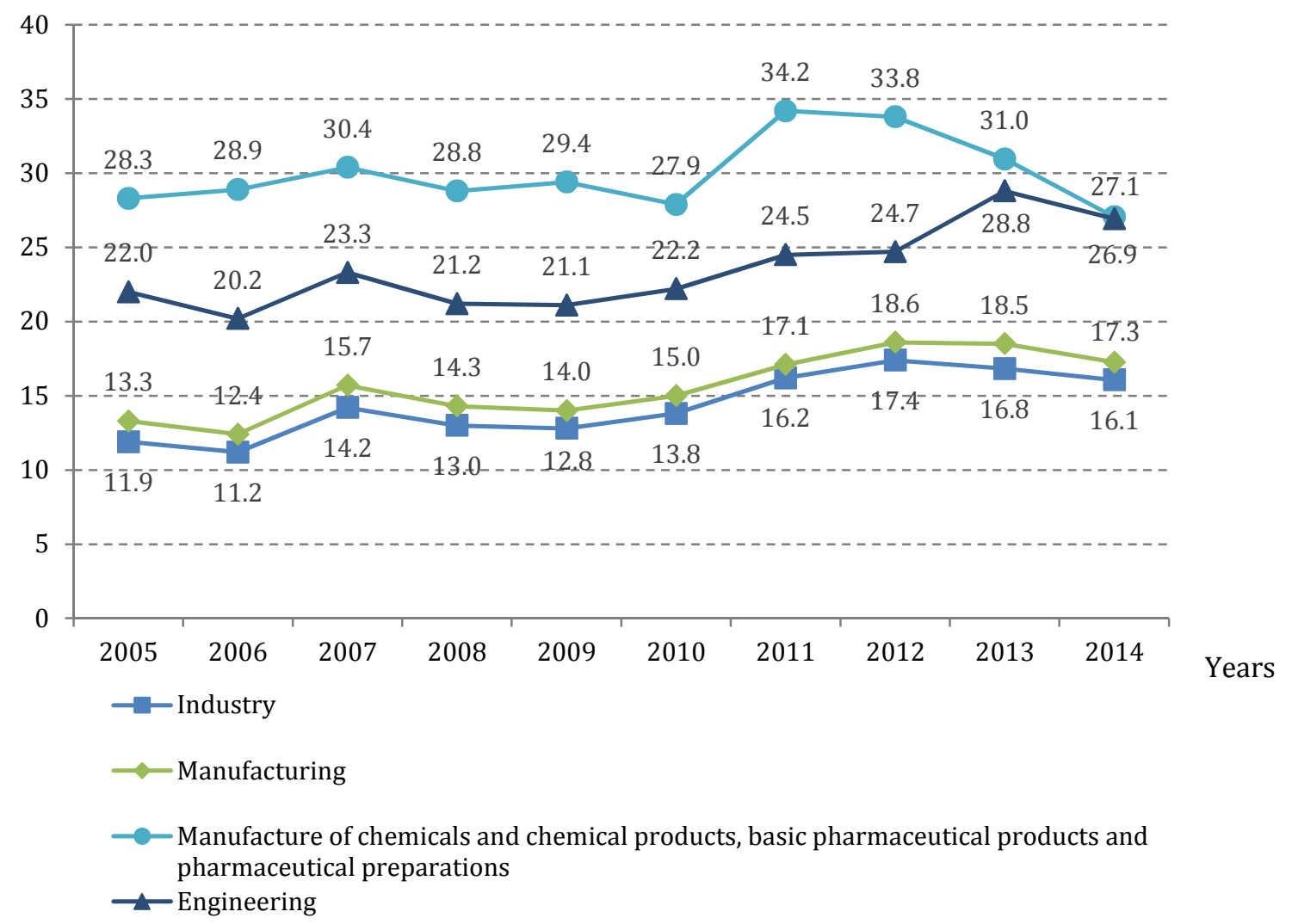

Fig. 5. Dynamics of the share of businesses engaging in innovational activity by separate types of industrial activity Source: Author's

A positive trend is the increase in innovational activity of engineering enterprises from $22 \%$ in 2005 to $26.9 \%$ in 2014.

The analysis of the correlation interactions showed a close connection between the innovational activity of engineering enterprises and businesses in the chemical industry (0.81), the manufacture of plastics $(0.74)$ and the manufacture of food products (0.86). The interaction among the rest of the industries is medium, with the exception of the manufacture of furniture and other products, the correlation with which is absent $(0.08)$. Thus, we can assume that intensification of innovational activity in one industry can contribute to an increase in the share of innovational activity of businesses in other industries. 
In general, in terms of the number of innovation-active businesses, the vast majority of industries are in the maturity phase, with the exception of the manufacture of coke and refined petroleum products, which is in decline.

In order to identify the trends and significance of changes in the innovational activity of enterprises in various industries, an estimation of the difference in the average values for the two sub-periods using the Student's criterion was carried out.

In terms of the share of volumes of realised innovative products in the total volume of sales, both for Ukrainian industry as a whole and for most of its individual industries, a significant decrease was observed. Critical changes in the dynamics of the volumes of innovative products took place in 2008-2010. In this case, the indicator decreased almost 2 times across the industries, except the manufacture of chemical and pharmaceutical products, where the volume decreased 5 times.

Similarly, the share of innovative products sold abroad in the production volume of most industries declined considerably. The period 2013-2014 appeared to be critical, which is largely due to the loss of traditional product markets in Russia and the CIS countries.

Testing the hypotheses about change in the stages of development showed that a change in the stage from maturity to decline took place in the mining industry and most manufacturing industries. Only in several industries, such as the manufacture of textiles, the manufacture of coke and refined petroleum products, and non-specific engineering, such changes were not observed, which allows the determination of their stage of development as maturity. But the dynamics of the volume of innovative products is very volatile in these industries, which creates the risk of transition to the phase of decline.

The financing of innovational activity also had some unstable dynamics during 2005-2014. To carry out the analysis and exclude inflationary effects, the data on the amount of financing were deflated using producer price indices. The dynamics of the expenditure on innovational activity is shown in Figure 6.

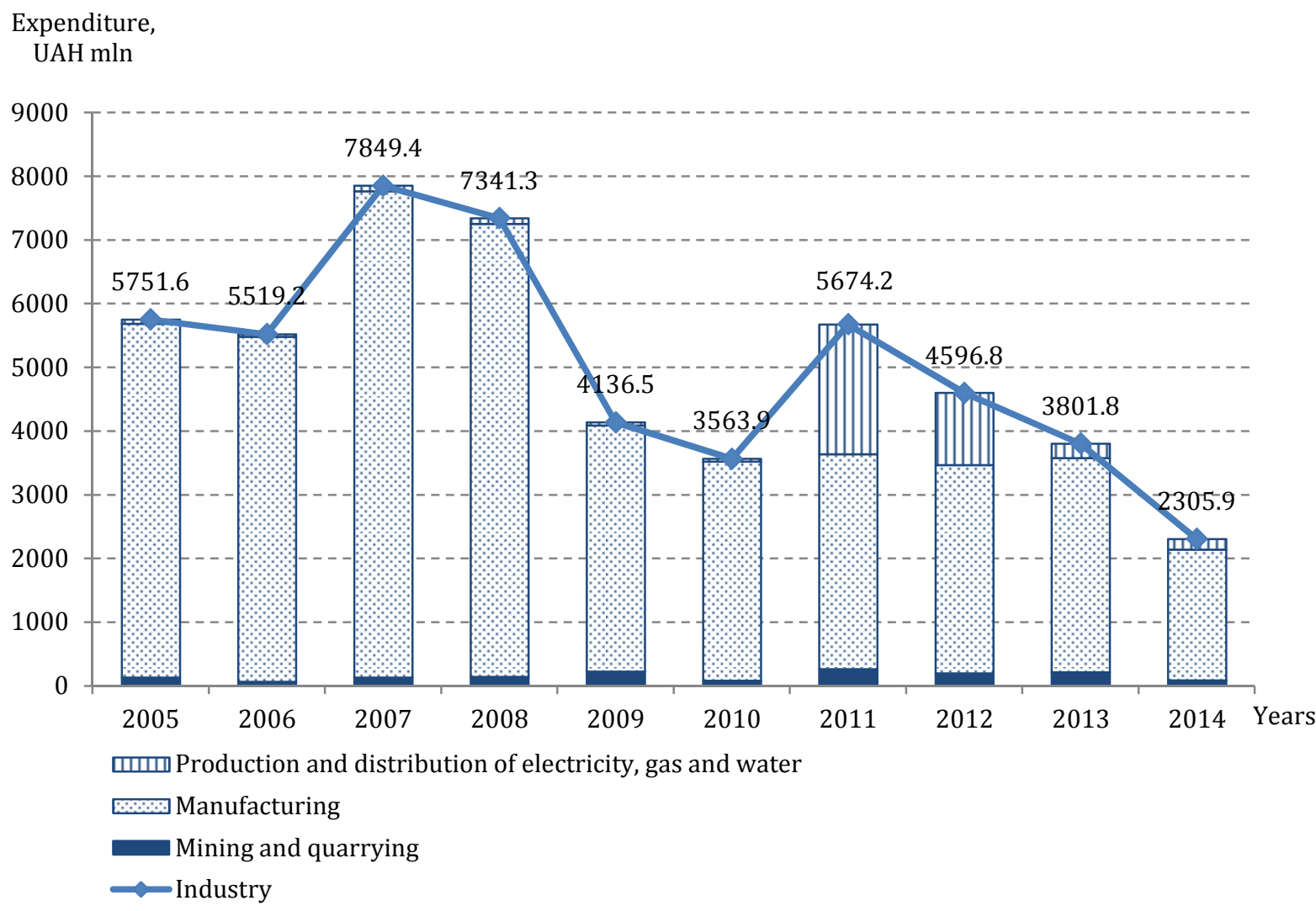

Fig. 6. Dynamics of the expenditure on innovational activity in Ukrainian industry Source: Author's 
As can be seen, manufacturing industry faced a reduction in expenditure on innovational activity. A burst of financing was observed only in the supply of electricity, gas, water, etc. in 2011-2012.

A detailed analysis of the rate of change in expenditure on innovational activity shows that the stage of development of the national industry in general and the manufacturing industry in particular is characterised as decline. The mining and quarrying industry, the manufacture of food, and the manufacture of textiles are in the stage of maturity. Two manufacturing industries - the manufacture of wood and the products of wood, and manufacture of furniture are in the stage of growth, as the expenditure on innovational activity has increased significantly.

The generalised results of the identification of the stage of the industries' development by all the applied criteria are shown in Table 3.

Table 3. Identification of the stages of the industries' development based on the system of criteria

\begin{tabular}{|c|c|c|c|c|c|c|c|}
\hline \multirow[b]{2}{*}{$\begin{array}{l}\text { Type of industrial } \\
\text { activities }\end{array}$} & \multicolumn{6}{|c|}{ Criteria } & \multirow[b]{2}{*}{$\begin{array}{c}\text { Generalised } \\
\text { stage }\end{array}$} \\
\hline & $\begin{array}{l}\text { Number of } \\
\text { businesses }\end{array}$ & $\begin{array}{l}\text { Number of } \\
\text { employees }\end{array}$ & $\begin{array}{c}\text { Volume of } \\
\text { production } \\
\text { of key } \\
\text { products }\end{array}$ & $\begin{array}{l}\text { Innovation- } \\
\text { active } \\
\text { enterprises }\end{array}$ & $\begin{array}{l}\text { Volume of } \\
\text { sales of } \\
\text { innovative } \\
\text { products }\end{array}$ & $\begin{array}{c}\text { Financing of } \\
\text { innovation } \\
\text { activity }\end{array}$ & \\
\hline 1 & 2 & 3 & 4 & 6 & 7 & 8 & 9 \\
\hline Industry & maturity & decline & maturity & maturity & maturity & decline & $\begin{array}{l}\text { risk of } \\
\text { decline }\end{array}$ \\
\hline $\begin{array}{l}\text { Mining and } \\
\text { manufacturing }\end{array}$ & maturity & decline & maturity & maturity & maturity & maturity & $\begin{array}{l}\text { risk of } \\
\text { decline }\end{array}$ \\
\hline Mining and quarrying & growth & decline & decline & maturity & maturity & maturity & $\begin{array}{l}\text { risk of } \\
\text { decline }\end{array}$ \\
\hline $\begin{array}{l}\text { Extraction of fuel and } \\
\text { energy minerals }\end{array}$ & decline & decline & decline & maturity & maturity & maturity & $\begin{array}{l}\text { risk of } \\
\text { decline }\end{array}$ \\
\hline $\begin{array}{l}\text { Extraction of minerals, } \\
\text { except fuel and energy }\end{array}$ & growth & decline & maturity & maturity & maturity & maturity & $\begin{array}{l}\text { risk of } \\
\text { decline }\end{array}$ \\
\hline Manufacturing & decline & decline & maturity & maturity & maturity & decline & decline \\
\hline $\begin{array}{l}\begin{array}{l}\text { Manufacture of food } \\
\text { products, beverages } \\
\text { and tobacco products }\end{array} \\
\end{array}$ & decline & decline & growth & maturity & decline & maturity & $\begin{array}{l}\text { risk of } \\
\text { decline }\end{array}$ \\
\hline $\begin{array}{lr}\text { Manufacture } & \text { of } \\
\text { textiles, } & \text { wearing } \\
\text { apparel, leather, } \\
\text { leather products and } \\
\text { other materials }\end{array}$ & decline & decline & maturity & maturity & maturity & maturity & $\begin{array}{l}\text { risk of } \\
\text { decline }\end{array}$ \\
\hline $\begin{array}{lr}\begin{array}{l}\text { Manufacture of } \\
\text { leather, leather } \\
\text { products and other } \\
\text { materials }\end{array} & \\
\end{array}$ & decline & decline & growth & maturity & maturity & maturity & $\begin{array}{l}\text { risk of } \\
\text { decline }\end{array}$ \\
\hline $\begin{array}{l}\text { Manufacture of wood } \\
\text { and of products of } \\
\text { wood and cork, except } \\
\text { furniture }\end{array}$ & decline & decline & decline & maturity & decline & growth & decline \\
\hline $\begin{array}{l}\text { Pulp and paper } \\
\text { production, publishing } \\
\text { activities }\end{array}$ & decline & decline & maturity & maturity & decline & growth & $\begin{array}{l}\text { risk of } \\
\text { decline }\end{array}$ \\
\hline $\begin{array}{l}\text { Manufacture of coke } \\
\text { and refined petroleum } \\
\text { products }\end{array}$ & decline & decline & maturity & decline & maturity & decline & decline \\
\hline $\begin{array}{l}\text { Manufacture of } \\
\text { chemicals and chemical } \\
\text { products }\end{array}$ & maturity & decline & decline & maturity & decline & decline & decline \\
\hline $\begin{array}{l}\text { Manufacture of rubber } \\
\text { and plastic products }\end{array}$ & growth & decline & maturity & maturity & decline & decline & $\begin{array}{l}\text { risk of } \\
\text { decline }\end{array}$ \\
\hline
\end{tabular}




\begin{tabular}{|c|c|c|c|c|c|c|c|}
\hline \multirow{2}{*}{$\begin{array}{c}\text { Type of industrial } \\
1\end{array}$} & \multicolumn{6}{|c|}{ Criteria } & \multirow{2}{*}{$\begin{array}{c}\text { Generalised } \\
9 \\
\end{array}$} \\
\hline & 2 & 3 & 4 & 6 & 7 & 8 & \\
\hline $\begin{array}{l}\text { Manufacture of other } \\
\text { non-metallic mineral } \\
\text { products }\end{array}$ & maturity & decline & - & maturity & maturity & growth & $\begin{array}{l}\text { risk of } \\
\text { decline }\end{array}$ \\
\hline $\begin{array}{lr}\text { Manufacture of } & \text { basic } \\
\text { metals, fabricated } \\
\text { metal products, except } \\
\text { machinery r } \\
\text { equipment }\end{array}$ & growth & decline & maturity & maturity & decline & decline & $\begin{array}{l}\text { risk of } \\
\text { decline }\end{array}$ \\
\hline Engineering & decline & decline & decline & maturity & decline & decline & decline \\
\hline $\begin{array}{l}\text { Manufacture of } \\
\text { computer, electronic } \\
\text { and optical products }\end{array}$ & decline & decline & decline & maturity & decline & decline & decline \\
\hline $\begin{array}{lr}\text { Manufacture } & \text { of } \\
\text { machinery } & \text { and } \\
\text { equipment } & \text { not } \\
\text { elsewhere classified }\end{array}$ & decline & decline & maturity & growth & maturity & decline & $\begin{array}{l}\text { risk of } \\
\text { decline }\end{array}$ \\
\hline $\begin{array}{ll}\text { Manufacture } & \text { of } \\
\text { vehicles }\end{array}$ & decline & decline & decline & maturity & decline & decline & decline \\
\hline $\begin{array}{l}\text { Supply of electricity, gas, } \\
\text { steam and air } \\
\text { conditioning }\end{array}$ & maturity & decline & decline & growth & maturity & growth & $\begin{array}{l}\text { risk of } \\
\text { decline }\end{array}$ \\
\hline
\end{tabular}

Note. ${ }^{*}$ The investment component is excluded from the final calculation due to the inadequacy of identifying the development stages of the industries.

\author{
Source: Author's
}

\title{
Summary and conclusions
}

The results of the assessment of the development stages demonstrate that almost all industries have passed the maturity phase and are on the verge of maturity and decline, or are already in the phase of decline, both by the majority of volumetric criteria and by innovation criteria.

The presence of a certain potential for innovational development is confirmed by the fact that in terms of the innovational criteria the industries that specialise in the manufacturing of wood and the products of wood are in the phase of growth. In some engineering industries (the manufacture of machinery and equipment not elsewhere classified), there are positive growth trends in the innovational activity of businesses. In general, the chemical and engineering industries, which have the highest level of technological development, are in the decline phase.

Thus, the trends revealed in the development of the national industry as a whole and the identification of the stages of development of individual industries makes it possible to draw a conclusion on the low level of efficiency of the Ukrainian economy, which is the result of long de-industrialization and the transition of most industries to the phase of decline. The reconstruction of industry should be aimed at technological upgrading, the activation of innovational activity, the stimulation of employment by attracting investment to create hightech industries and fundamentally upgrade the existing ones.

\section{References}

[1] V.Ye. Khaustova, Industrial policy in Ukraine: formation and forecasting: monograph, Kharkiv, 2015.

[2] K. Warwick, Beyond Industrial Policy: Emerging Issues and New Trends // OECD Science, Technology and Industry Policy Papers, 2, OECD Publishing, Paris, 2013, 57. http://dx.doi.org/10.1787/5k4869clw0xp-en [01.12.2017]

[3] A.V. Novickaya, Strategic alternatives of the organization development on the view of the stage of the life cycle of the market, Vestnik Universiteta, State University of Management, 11 (2012) 126-131.

[4] O. Y. Lotysh, Features strategic analysis of sector, Efficient economy: Electronic scientific professional edition, 2016, 11: http://www.economy.nayka.com.ua/?op=1\&z=5258 [12.12.2017]

[5] O.I. Matiushenko, Enterprise Life Cycle: Essence, Models, Estimation, The Problems of Economy, 4 (2010) 82-91. 
[6] S.M. Smirnova, Assessment of the stage of industrial cluster development: modeling approaches, Materials of the scientific-practical conference "The role of business in the transformation of Russian society. Economic and Applied Problems of System Management: Current Trends", 2014, pp. 214-218.

[7] N.S. Rychihina, Analysis of stages of «life cycle» of development textile branch of the Ivanovo region (Russia), Economics and banks 2 (2013) 88-96.

[8] N.S. Rychihina, The analysis of life cycle and processes of spontaneous restructuring of machine-building industry in the region, Regional economics: theory and practice 365 (2014) 10-21.

[9] A. Bonaccorsi, P. Giuru, Industry life cycle and the evolution of an industry network, Laboratory of Economic and Management Sant'Anna School of Advanced Studies, Working Paper Series, 2000, 4, 46 http://www.lem.sssup.it/WPLem/files/2000-04.pdf [20.12.2017]

[10] A. Sabol, M. Šander, D. Fučkan, The concept of industry life cycle and development of business strategies, International conference "Active Citizenship by Management, Knowledge Management \& Innovation Knowledge and Learning", Zadar, 2013, pp. 635-642.

[11] J. Krafft, J.-L. Ravix, The firm and its governance along the industry life cycle, In: B. Laperche, D. Uzunidis (Eds.), Powerful Finance and Innovation Trends in High-Risk Economy, Palgrave MacMillan, London, 2008. pp. 131-148. https://hal.archives-ouvertes.fr/hal-00211206 [20.12.2017]

[12] L.S. Valinurova, N.A. Kuz'minyh, Assessment of the level of innovative development of industries, Innovations 104 (2007) 42-47.

[13] S.G. Kuznetsov, Allocation of Industry Cycles in the Forest Sector of Russia Using the Principle of Innovation Exhaustion, Science prospects 68 (2015) 93-96.

[14] L.V. Strelkova, S.S. Kabanov, Technological development of industry branches: assessment and prospects, Vestnik of Lobachevsky State University of Nizhni Novgorod 2 (2012) 247-251.

[15] M. Sanders, J. Bos, C. Economidou, R\&D over the life cycle, Tjalling C. Koopmans Research Institute Discussion Paper Series, 26 (2007) 07-18. http://www.koopmansinstitute.uu.nl [04.01.2018]

[16] O. Skotarenko, L. Babkina, Choice of strategies for changing the stages of the life cycle of points of economic growth in the regions of the Russian Federation, Risk: Resources, Information, Supply, Competition 3 (2013) 124-128.

[17] O.S. Kozlova, The impact of the regional phases of the oil extraction life cycle on the duration of the sector's life cycle, Bulletin of Baikal State University 27 (2017) 27-31.

[18] E.V. Krasil'nikova, Economic-mathematical modeling of transition to a stage of rapid growth and evaluation of micro and mezo-factors, Electronic scientific and practical journal "Synergy" 6 (2016) 54-60.

[19] S. Tavassoli, Innovation Determinants over Industry Life Cycle. Department of Industrial Economics, Blekinge Institute of Technology, Center for Strategic Innovation Research Electronic Working paper Series, Karlskrona, Sweden 11 (2012) 34.

[20] T. Grebel, L. Krafft, P.P. Saviotti, On the life cycle of knowledge intensive sectors, Revue de I'OFCE, Presses de Sciences Po, special issue (2006) 63-85. https://hal.archives-ouvertes.fr/hal-00203585 [04.01.2018]

[21] M. van Dijk, Industry life cycle in Dutch manufacturing, Working paper, UNU-MERIT Research Memoranda, Maastricht 14 (1998) 34. http://citeseerx.ist.psu.edu/viewdoc/download?doi=10.1.1.199.5305\&rep =rep1\&type=pdf [04.01.2018]

[22] M.D. Madvar, H. Khosropour, A. Khosravanian, M. Mirafshar et. al. Patent-based technology life cycle analysis: the case of the petroleum industry, Foresight and STI governance 10 (2016) 72-79. DOI: 10.17323/1995-459X.2016.4.72.79

[23] State Statistics Service of Ukraine. Official Site: www.ukrstat.gov.ua [20.02.2018]

[24] Industry of Ukraine in 2007-2010. Statistical Publication. State Statistics Service of Ukraine, Kyiv, 2011.

[25] Industry of Ukraine in 2011-2015. Statistical Publication. State Statistics Service of Ukraine, Kyiv, 2016.

[26] Statistical Yearbook 2007. Statistical Publication. State Statistics Service of Ukraine, Kyiv, 2008.

[27] Statistical Yearbook 2010. Statistical Publication. State Statistics Service of Ukraine, Kyiv, 2011. 